\title{
Protocols for large scale in situ hybridization on C. elegans larvae ${ }^{*}$
}

Tomoko Motohashi, Hiroaki Tabara, Yuji Kohara ${ }^{\S}$, Genome Biology Lab Center for Genetic Resource Information, National Institute of Genetics, Mishima 411-8540, Japan

\section{Table of Contents}

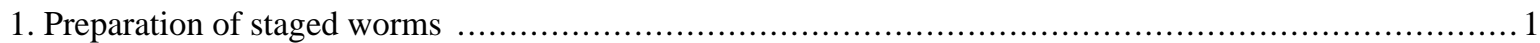

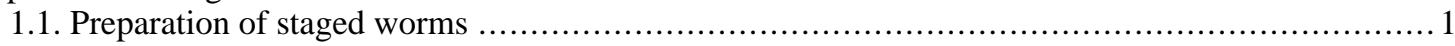

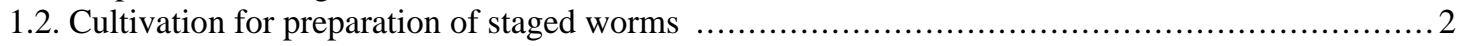

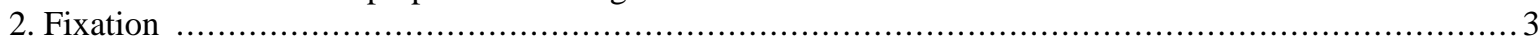

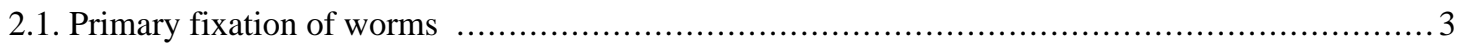

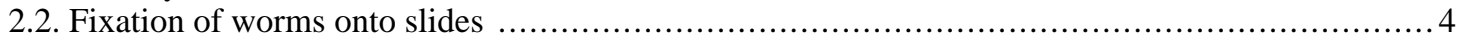

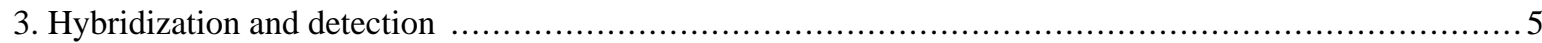

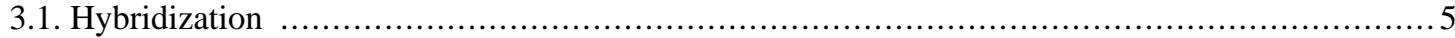

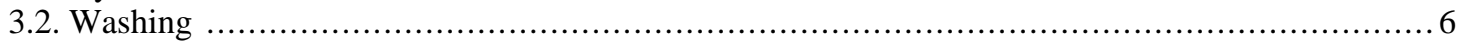

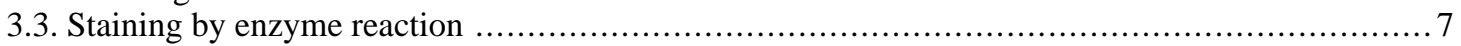

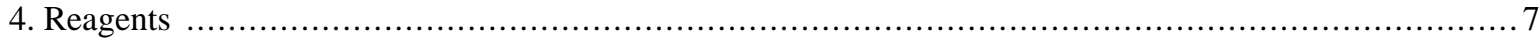

\section{Preparation of staged worms}

\subsection{Preparation of staged worms}

1. Sieve a liquid culture containing a lot of gravid worms through nylon mesh $(50 \mu \mathrm{ml})$.

2. Clean up the collected worms thoroughly with DW on the nylon mesh.

3. Wash off the worms on the mesh with DW into a beaker.

4. Transfer the worms into a $50 \mathrm{ml}$ centrifuge tube.

5. Wash the worms by centrifugation (2000rpm for $1 \mathrm{~min}$ at $\left.4^{\circ} \mathrm{C}\right)$.

*Edited by Oliver Hobert. WormMethods editor, Victor Ambros. Last revised April 27, 2005. Published July 24, 2006. This chapter should be cited as: Motohashi, T. et al. Protocols for large scale in situ hybridization on C. elegans larvae (July 24, 2006). WormBook, ed. The C. elegans Research Community, WormBook, doi/10.1895/wormbook.1.103.1, http://www.wormbook.org.

Copyright: (c) 2006 Tomoko Motohashi et al. This is an open-access article distributed under the terms of the Creative Commons Attribution License, which permits unrestricted use, distribution, and reproduction in any medium, provided the original author and source are credited.

${ }^{\S}$ To whom correspondence should be addressed. Email: ykohara@lab.nig.ac or isugiura@lab.nig.ac.jp. 
6. Aspirate the sup.

7. Measure the packed volume of the worms.

- If it is $2-3 \mathrm{ml}$, add DW to $10 \mathrm{ml}$.

- If it is $3-5 \mathrm{ml}$, add DW to $12.5 \mathrm{ml}$.

- If it is larger than $5 \mathrm{ml}$, divide the worms into multiple tubes.

8. Add equal volume of $2 \mathrm{X}$ alkaline-bleach solution and mix gently.

\section{X alkaline-bleach solution}

$\begin{array}{ll}\mathrm{NaClO} & 3 \mathrm{ml} \\ 5 \mathrm{M} \mathrm{KOH} & 2.5 \mathrm{ml} \\ \mathrm{DW} & 19.5 \mathrm{ml}\end{array}$

9. Lay the tube down, monitoring the breakage of the worms under a dissecting microscope.

10. When about $30 \%$ of the worms begin to break apart (usually 5-10 min later), load the suspension into a $50 \mathrm{ml}$ disposable syringe.

11. Force it out through a needle (23G6) into a $50 \mathrm{ml}$ Falcon tube.

12. Filtrate the suspension through a $50 \mathrm{~mm}$ nylon mesh, and wash the debris with $\mathrm{M} 9$ on the mesh to recover the trapped eggs.

13. Transfer the filtrate into $50 \mathrm{ml}$ Falcon tubes.

14. Collect and wash eggs by centrifugation at 3000rpm for $1 \mathrm{~min}$ once and at 2000rpm for $1 \mathrm{~min}$ twice at $4^{\circ} \mathrm{C}$.

15. Transfer the eggs into $15 \mathrm{ml}$ Falcon tube and centrifuge at 2000rpm for $1 \mathrm{~min}$ at $4{ }^{\circ} \mathrm{C}$.

16. Measure the packed volume of the eggs.

\subsection{Cultivation for preparation of staged worms}

To cover all larval stages, synchronization at $\mathrm{L} 1$ is not performed. We usually cultivate worms at $20^{\circ} \mathrm{C}$.

1. Mix the eggs, S-basal and E.coli OP-50 suspension in a new $1 \mathrm{~L}$ flask as follows:

\begin{tabular}{|c|c|c|c|c|c|}
\hline & Eggs & S-basal & OP-50 & Collect after & $\begin{array}{c}\text { Expected vol of } \\
\text { worms }\end{array}$ \\
\hline For L1-L2 & $100 \mu \mathrm{l}$ & $200 \mathrm{ml}$ & $30 \mathrm{ml}$ & $20-24 \mathrm{hrs}$ & $150-200 \mu \mathrm{l}$ \\
\hline For L2-L3 & $100 \mu \mathrm{l}$ & $200 \mathrm{ml}$ & $80 \mathrm{ml}$ & $48 \mathrm{hrs}$ & $500 \mu \mathrm{l}$ \\
\hline For L3-L4 & $50 \mu \mathrm{l}$ & $200 \mathrm{ml}$ & $50 \mathrm{ml}$ & $60 \mathrm{hrs}$ & $500 \mu \mathrm{l}$ \\
\hline For L4-adult & $50 \mu \mathrm{l}$ & $200 \mathrm{ml}$ & $90 \mathrm{ml}$ & $70-72 \mathrm{hrs}$ & $2.5 \mathrm{ml}$ \\
\hline
\end{tabular}

2. After appropriate time, collect worms by: for L3 adults, sieving through $50 \mu 1$ nylon mesh and washing off with M9 into a 50ml Falcon tube. For L1-L2, centrifugation at 2000rpm and $4^{\circ} \mathrm{C}$ for $1 \mathrm{~min}$.

3. Wash the worms with $\mathrm{M} 9$ by centrifugation $\left(2000 \mathrm{rpm}, 4^{\circ} \mathrm{C}\right.$ for $\left.1 \mathrm{~min}.\right)$.

4. Transfer the worms into $2 \mathrm{ml}$ eppendorf tubes at $200 \mu \mathrm{l}$ (packed volume) worms per tube.

5. Centrifuge the tubes at $3500 \mathrm{rpm}$ for $10 \mathrm{sec}$ at $4^{\circ} \mathrm{C}$. 
6. Let the tubes stand for $30 \mathrm{sec}$ to settle the worms down to the bottom.

7. Remove the sup using aspirator (This procedure will be used for changing buffer in the subsequent steps.).

\section{Fixation}

\subsection{Primary fixation of worms}

1. Add $10 \mathrm{mM}$ DTT, $0.1 \%$ Tween- 20 in $1 \mathrm{X} \mathrm{BO}_{3}(\mathrm{pH} 9)$ equilibrated at $22^{\circ} \mathrm{C}$.

2. Rotate the tubes for $20 \mathrm{~min}$ at $22^{\circ} \mathrm{C}$.

3. Change the buffer to $\mathrm{PBS}\left(4^{\circ} \mathrm{C}\right)$, and rotate the tubes for $2 \mathrm{~min}$ at r.t.

4. Repeat step 3 once.

5. ProteinaseK digestion:
a. $\quad$ Add PBT (at $22^{\circ} \mathrm{C}$ ) to total $1 \mathrm{ml}$.
b. Add $5 \mu \mathrm{l}$ of ProteinaseK $(20 \mathrm{mg} / \mathrm{ml})$.
c. Rotate the tubes for $12 \mathrm{~min}$ at $22^{\circ} \mathrm{C}$.

6. Change the buffer to Glycine in PBT (at $4^{\circ} \mathrm{C}$ ) and rotate the tubes for 2 min at r.t.

7. Change the buffer to PBS and rotate for $2 \mathrm{~min}$ at r.t.

8. Repeat step 7 twice.

9. Fixation with Dent: Change the buffer to Dent $(\mathrm{MeOH}: \mathrm{DMSO}=8: 2)$ pre-cooled at $-20^{\circ} \mathrm{C}$, and rotate for $5 \mathrm{~min}$ in cold room.

10. Rehydration: Change the buffer and rotate the tubes as follows:

\begin{tabular}{|c|c|c|}
\hline $\mathrm{MeOH}$ & $4^{\circ} \mathrm{C}$ & $5 \mathrm{~min}$ \\
\hline $\mathrm{MeOH}: 0.2 \mathrm{~N} \mathrm{HCl}=1: 1$ & $4^{\circ} \mathrm{C}$ & $10 \mathrm{~min}$ \\
\hline PBS & $4^{\circ} \mathrm{C}$ & $2 \mathrm{~min}$ \\
\hline PBS & $22^{\circ} \mathrm{C}$ & $5 \mathrm{~min}$ \\
\hline $10 \mathrm{mM}$ DTT in $1 \mathrm{X} \mathrm{BO}_{3}(\mathrm{pH} 9)$ & $22^{\circ} \mathrm{C}$ & $10 \mathrm{~min}$ \\
\hline $1 \mathrm{X} \mathrm{BO}_{3}(\mathrm{pH} 9)$ & $22^{\circ} \mathrm{C}$ & $3 \mathrm{~min}, 2 \mathrm{~min}, 2 \mathrm{~min}$ (3 times) \\
\hline $\begin{array}{l}0.6 \% \mathrm{H}_{2} \mathrm{O}_{2} \text { in } 1 \mathrm{X} \mathrm{BO}_{3} \\
\left(\mathrm{Add} 1 \mathrm{X} \mathrm{BO}_{3} \text { to total } 1 \mathrm{ml} \text { and then add } 20 \mu \mathrm{l} \text { of } 30 \%\right. \\
\left.\mathrm{H}_{2} \mathrm{O}_{2}\right)\end{array}$ & $22^{\circ} \mathrm{C}$ & $10 \mathrm{~min}$ \\
\hline PBS & $22^{\circ} \mathrm{C}$ & 2 min (3 times) \\
\hline $\begin{array}{l}3.7 \% \text { formaldehyde in hepes-PBS } \\
\text { (Freshly prepared and stored in a refrigerator until use.) }\end{array}$ & $22^{\circ} \mathrm{C}$ & $2 \mathrm{hrs}$ \\
\hline
\end{tabular}


11. Dehydration: Change the buffer and rotate the tubes at r.t. as follows:

$\begin{array}{ll}\text { EtOH:PBS }=3: 7 & 5 \mathrm{~min} \\ \text { EtOH:PBS }=1: 1 & 5 \mathrm{~min} \\ \text { EtOH:PBS }=7: 3 & 5 \mathrm{~min} \\ \text { EtOH } & 5 \mathrm{~min} \text { (twice) }\end{array}$

12. Store the fixed worms at $-20^{\circ} \mathrm{C}$ in $\mathrm{EtOH}$.

\subsection{Fixation of worms onto slides}

1. Resuspend the fixed worms (stored in $\mathrm{EtOH}$ at $-20^{\circ} \mathrm{C}$ ) and quickly transfer the following volume (variable depending on the sample worms) of the suspension into siliconized $2 \mathrm{ml}$ eppendorf tubes:
L1-L2
ca. $200 \mu 1 /$ tube
L2-L3
ca. $300 \mu \mathrm{l} /$ tube
L3-L4
ca. $900 \mu 1 /$ tube
L4-adult
ca. $1100 \mu \mathrm{l} /$ tube

(The amounts of worms allows hybridization with 120 different probes.)

2. Rehydration: Change the buffer and rotate the tubes at r.t. as follows:

$\begin{array}{ll}\text { EtOH:PBS }=7: 3 & 5 \mathrm{~min} \\ \text { EtOH:PBS }=1: 1 & 5 \mathrm{~min} \\ \text { EtOH:PBS }=3: 7 & 5 \mathrm{~min}\end{array}$

3. Wash with PBT for 5 min $x 3$ times and resuspend in about $700 \mu l$ of PBT.

4. Check the density of the worms by counting worms in an aliquot of the suspension under a dissecting microscope.

5. Allow the worms to stick to slides as follows:

1. Place poly-L-lysine coated 8 well test slides on the top of an aluminum block pre-cooled on ice.

2. Dispense ice-cold PBS to individual wells at $30 \mu \mathrm{l} / \mathrm{well}$.

3. Dispense the rehydrated worms to individual wells at $5 \mu 1 /$ well as follows:

- $\quad$ L1-L2 is in the wells \#1 and 5

- $\quad$ L2-L3 is in the wells \#2 and 6

- $\quad$ L3-L4 is in the wells \#3 and 7

- $\quad$ L4-adult is in the wells \#4 and 8

4. Let stand for 5 min to settle the worms to the bottom.

6. Fix the worms as follows:

1. Soak the slides in $\mathrm{MeOH}$ pre-cooled at $4^{\circ} \mathrm{C}$ by arranging the slides in a stainless steel holder (15 slides/holder) that is placed in the $\mathrm{MeOH}$.

2. Let stand for $5 \mathrm{~min}$. 
3. Soak the holder with the slides in the following series of solution at $4^{\circ} \mathrm{C}$ in cold room:
$\mathrm{MeOH}$ :formaldehyde in hepes-PBS $=7: 3$
$2 \mathrm{~min}$
$\mathrm{MeOH}:$ formaldehyde in hepes-PBS $=1: 1$
$2 \mathrm{~min}$
$\mathrm{MeOH}:$ formaldehyde in hepes-PBS $=3: 7$
$2 \min$
$3.7 \%$ formaldehyde in hepes-PBS
$60 \mathrm{~min}$
PBT
5 min $x 5$ times at r.t.

7. ProteinaseK digestion:
a. Add $60 \mu \mathrm{l}$ of $20 \mathrm{mg} / \mathrm{ml}$ of ProteinaseK in $180 \mathrm{ml}$ of PBT pre-warmed at $37^{\circ} \mathrm{C}$ (final conc. $\mu \mathrm{g} / \mathrm{ml}$ ).
b. Mix well by stirring.
c. Transfer into a vat that fits the slide holder.
d. Soak the holder containing the slides in the ProteinaseK solution.
e. Incubate at $37^{\circ} \mathrm{C}$ for $30 \mathrm{~min}$.

8. Transfer the holder in glycine in PBT pre-cooled at $4{ }^{\circ} \mathrm{C}$ and let stand for 2 min to stop the digestion.

9. Acetylation
a. Soak in $0.1 \%$ Triethanol amine for $2 \mathrm{~min}$ at r.t.
b. Soak in $0.05 \%$ Acetic anhydride in Triethanol amine for $10 \mathrm{~min}$.

10. Dehydrate the specimen by soaking the holder in the following series of solution at r.t.:

$\begin{array}{ll}\text { PBT } & 2 \mathrm{~min} \\ \text { PBT } & 2 \mathrm{~min} \\ \text { formaldehyde in hepes-PBS } & 20 \mathrm{~min} \\ \text { EtOH:PBS }=3: 7 & 5 \mathrm{~min} \\ \text { EtOH:PBS }=1: 1 & 5 \mathrm{~min} \\ \text { EtOH:PBS }=7: 3 & 5 \mathrm{~min} \\ \text { EtOH } & 5 \mathrm{~min} \text { twice }\end{array}$

11. Store the slides in $\mathrm{EtOH}$ at $-80^{\circ} \mathrm{C}$.

\section{Hybridization and detection}

\subsection{Hybridization}

1. Take the fixed slides, arrange in a stainless holder and immersed in $\mathrm{EtOH}$.

2. Rehydrate the specimen by soaking the holder in the following series of solutions:

$\begin{array}{ll}\text { EtOH:PBS }=7: 3 & 5 \mathrm{~min} \\ \text { EtOH:PBS }=1: 1 & 5 \mathrm{~min} \\ \text { EtOH:PBS = 3:7 } & 5 \mathrm{~min} \\ \text { PBT } & 5 \mathrm{~min} \\ 50 \% \text { formamide, 5XSSC, } 100 \mu / \mathrm{ml} \text { heparin, } 0.1 \% & 10 \mathrm{~min} \\ \text { Tween:PBT = } 1: 1 & \\ 50 \% \text { formamide, 5XSSC, } 100 \mu / \mathrm{ml} \text { heparin, } 0.1 \% & 10 \mathrm{~min}\end{array}$

Tween 
3. Prehybridization

a. Take out the slides using forceps, wipe off the outside of the wells and draw a rectangle surrounding the 8 wells using a IMMUNO pen.

b. Pour $250 \mu \mathrm{l}$ of hybridization solution (heat-denatured at $99^{\circ} \mathrm{C}$ for $10 \mathrm{~min}$. and quickly chilled on ice-water for $5 \mathrm{~min}$ ) inside the rectangle.

c. Placed the slides in a moisture box.

d. Place the moisture box in an oven at $48^{\circ} \mathrm{C}$ for $1 \mathrm{hr}$.

4. Heat denature probes as follows:

a. Dispense $9 \mu 1$ probe solution/well into 4 contiguous wells (e.g., A1-A4), since one probe is applied to 4 wells (for 4 different larval stages).

b. Dispense $41 \mu 1$ of hybridization solution/well and mix by pipetting.

c. Seal the plate using GeNunc Tape and centrifuge.

d. Place the plate on a heated block at $99^{\circ} \mathrm{C}$ for $10 \mathrm{~min}$ and quickly chill on ice for $5 \mathrm{~min}$.

5. Assembling of hybridization apparatus (S\&S 96 well dot blotting apparatus):

a. Place a silicon sheet (1 mm thick) on the top of the lower block.

b. Clean up the surface of the silicon sheet with EtOH.

c. Apply O-rings to the holes at the 4 corners and the holes used for hybridization of the upper 96-hole block.

d. Take out the pre-hybridized slides, drain off the hybridization solution by tapping on the top of paper towel.

e. Quickly arrange 4 slides at the fixed positions on the silicon sheet on the lower block.

f. Cover the slides with the upper block and rock the complex.

6. Start of hybridization:

a. Apply all of the heat denatured probes using a 4-channel pipette.

b. Add $100 \mu 1$ of mineral oil per well.

c. Seal the holes of the apparatus with microtiter plate sealing tape.

d. Place the hybridization apparatus in a air-tight box.

e. Incubate at $48^{\circ} \mathrm{C}$ overnight.

\subsection{Washing}

1. Pre-warm the following solutions:

- solution-1: $50 \%$ formamide, $5 \mathrm{XSSC}, 100 \mu \mathrm{g} / \mathrm{ml}$ heparin, $0.1 \%$ Tween $: \mathrm{PBT}=1: 1$

- solution-2: 0.8xPBS, $0,1 \%$ CHAPS

2. Dispense solution-1 into the hybridization holes (to dilute the probes). 
3. Discard the solution in the holes by decantation.

4. Disassemble the apparatus, take the slides and arrange them in a holder soaked in solution-1.

5. Shake for $2 \mathrm{~min}$ in a $48^{\circ} \mathrm{C}$ incubator.

6. Transfer the holder containing the slides into a new vat containing solution- 1 and shake for $10 \mathrm{~min}$ in the $48^{\circ} \mathrm{C}$ incubator. Repeat once.

7. Transfer the holder into a new vat containing solution- 2 and shake for 20 min in the $48^{\circ} \mathrm{C}$ incubator. Repeat 3 times.

8. Transfer the holder into a new vat containing 1xPBT and shake for $5 \mathrm{~min}$ at r.t. Repeat once.

You may store the slides in $1 \mathrm{xPBT}$ at $4^{\circ} \mathrm{C}$ overnight.

\subsection{Staining by enzyme reaction}

1. Transfer the holder containing the slides into a vat containing PBtr (PBS, $0.1 \%$ Triton-X100, $0.1 \%$ BSA, $0.01 \%$ $\mathrm{NaN}_{3}$ ) and shake for $1.5 \mathrm{hr}$ at r.t.

2. Take individual slides, remove the solution outside the wells and overwrite the rectangle using a PAP pen.

3. Apply $250 \mu \mathrm{l}$ of diluted anti-DIG antibody solution (diluted 1:2500 with PBtr) per slide.

4. Place the slides in a moist box.

5. Incubate for $2 \mathrm{hrs}$ at r.t., or overnight at $4^{\circ} \mathrm{C}$ in the dark.

6. Transfer the slides into a vat containing PBtr (PBS, 0.1\% Triton-X100, 0.1\% BSA, 0.01\% NaN 3 ) and shake for 10 min at r.t. Repeat 3 times.

7. Soak the slides in stain buffer $\left(100 \mathrm{mM} \mathrm{NaCl}, 5 \mathrm{mM} \mathrm{MgCl}_{2}, 100 \mathrm{mM}\right.$ TrisHCl pH9.5, 0.1\% Tween, $1 \mathrm{mM}$ levamisol) and shake for $5 \mathrm{~min}$ at r.t. Repeat once.

8. Arrange the slides in glass vats (max. 8 slides per vat) containing the stain buffer.

9. Prepare the coloring solution by mixing $40 \mathrm{ml}$ of the stain buffer (at $22 \% \mathrm{C}$ ), $180 \mu \mathrm{l}$ of NBT and $140 \mu \mathrm{l}$ of BCIP.

10. Decant the stain buffer from the glass vat preventing the coming out of the slides, and add the coloring solution into the vat.

11. Incubate for $1 \mathrm{hr} 15 \mathrm{~min}$ in a $22^{\circ} \mathrm{C}$ incubator.

12. Wash the slides 3 times with PBS, 20mM EDTA to terminate the coloring reaction.

13. The slides can be stored in PBS, 20mM EDTA overnight at $4^{\circ} \mathrm{C}$.

14. Mount the slides using glycerol solution.

15. Observe on a microscope equipped with Nomarski optics.

\section{Reagents}

\section{M9}

$\mathrm{KH}_{2} \mathrm{PO}_{4} \quad 3 \mathrm{~g}$

$\mathrm{Na}_{2}^{2} \mathrm{HPO}_{4}$

$1 \mathrm{M} \mathrm{MgSO}^{2} \mathrm{Me}_{4} \quad 1 \mathrm{ml}$

Add DW to total 1 liter and autoclave 
S-basal

$\mathrm{NaCl}$

$1 \mathrm{M} \mathrm{K}-\mathrm{PO}$ (pH6)

cholesterol $(5 \mathrm{mg} / \mathrm{ml}$ in $\mathrm{EtOH})$

Add DW to total 2 liter and autoclave

40X BO (pH9)

$\mathrm{H}_{3} \mathrm{BO}_{3} 1 \mathrm{M}^{3}$ Adjust $\mathrm{pH}$ to 9.0 using $\mathrm{NaOH}$ and autoclave

\section{PBS}

$\mathrm{NaCl}$

$\mathrm{KCl}$

$\mathrm{Na} \mathrm{HPO}_{4}$

$\mathrm{KH}_{2}^{2} \mathrm{PO}^{4}$

Adjust $\stackrel{4}{\mathrm{p} H}$ to 7.2 and autoclave

PBT

PBS $+0.1 \%$ Tween 20

\section{Glycine in PBT}

Glycine $2 \mathrm{mg} / \mathrm{ml}$ in PBS Autoclave, then add 0.1\% Tween 20 3.7\% Formaldehyde in hepes-PBS hepes buffer : formalin : $10 \mathrm{X}$ PBS $=8: 1: 1$ hepes buffer

$\begin{array}{ll}\text { Hepes } & 100 \mathrm{mM} \\ \mathrm{MgSO}^{4} & 2 \mathrm{mM} \\ \text { EGTA }^{4} & 0.04 \% \\ \text { Add NaOH to pH6.9 and autoclave } & \\ & \\ \text { Hybridization solution } & \\ \text { deionized formamide } & 50 \% \\ \text { SSC (pH7, autoclaved) } & 5 \mathrm{x} \\ \text { sonicated salmon testis DNA } & 100 \mu \mathrm{g} / \mathrm{ml} \\ \text { yeast tRNA } & 100 \mu \mathrm{g} / \mathrm{ml} \\ \text { heparin } & 100 \mu \mathrm{g} / \mathrm{ml} \\ \text { Tween } 20 & 0.1 \%\end{array}$

CHAPS (349-04722, DOJINDO, Japan)

IMMUNO pen (Wako, Japan)
$11.69 \mathrm{~g}$

$100 \mathrm{ml}$

$2 \mathrm{ml}$
$137 \mathrm{mM}$

$2.7 \mathrm{mM}$

$4.3 \mathrm{mM}$

$1.5 \mathrm{mM}$

All WormBook content, except where otherwise noted, is licensed under a Creative Commons Attribution License. 